\title{
PENGARUH LARUTAN ATONIK TERHADAP KANDUNGAN KARBOHIDRAT TERLARUT TOTAL PLANLET JERUK SIAM PONTIANAK (Citrus nobilis Lour. var. microcarpa Hassk.) SECARA IN VITRO
}

\author{
Nadya Rosyalina ${ }^{1}$, Endang Nurcahyani1 ${ }^{*}$, Hardoko I. Qudus ${ }^{2}$, Zulkifli $^{1}$ \\ 1. Jurusan Biologi FMIPA Universitas Lampung \\ 2. Jurusan Kimia FMIPA Universitas Lampung \\ Jl. Prof. Dr. Soemantri Brojonegoro No.1, Bandar Lampung, Indonesia 35145 \\ hardoko.insan@fmipa.unila.ac.id
}

\begin{tabular}{|l|}
\hline Artikel Info \\
Diterima \\
tanggal \\
20.01 .2018 \\
Disetujui \\
publikasi \\
tanggal \\
30.04.2018 \\
Kata kunci: \\
Citrus nobilis \\
Lour, PEG \\
6000, var \\
microcarpa \\
Hassk \\
\end{tabular}

\begin{abstract}
ABSTRAK
Jeruk siam pontianak (Citrus nobilis Lour. var. microcarpa Hassk.) salah satu komoditas buah-buahan penting di Indonesia. Jeruk yang mempunyai nilai ekonomis yang cukup tinggi baik dalam bentuk segar maupun olahan serta sebagai sumber vitamin dan mineral. Penelitian ini bertujuan untuk mengetahui konsentrasi larutan atonik yang optimum; konsentrasi Polyethylene Glycol (PEG) yang toleran terhadap cekaman kekeringan untuk seleksi planlet jeruk siam secara in vitro; mengetahui interaksi antara larutan atonik dengan PEG 6000 untuk mengetahui dan menganalisis karakter ekspresi spesifik pada planlet jeruk siam yang toleran terhadap cekaman kekeringan meliputi kandungan karbohdrat terlarut total. Penelitian ini dilakukan dalam percobaan faktorial $3 \times 3$. Faktor A adalah larutan atonik dengan 3 taraf konsentrasi : $0 \mathrm{~mL} / \mathrm{L}, 1 \mathrm{~mL} / \mathrm{L}$, dan $2 \mathrm{~mL} / \mathrm{L}$. Faktor B adalah PEG 6000 dengan 3 taraf konsentrasi: $0 \%$ b/v, $3 \%$ b/v, dan $5 \%$ b/v. Uji Levene, analisis ragam pada taraf nyata $5 \%$. Analisis ragam dilakukan pada taraf nyata $5 \%$. Hasil penelitian menunjukkan bahwa larutan atonik dan tingginya tingkat kekeringan berpengaruh nyata menurunkan kandungan karbohidrat terlarut total. Dari hasil penelitian dapat disimpulkan bahwa larutan atonik tidak berpengaruh nyata dalam peningkatan kandungan karbohidrat terlarut total pada planlet jeruk siam Pontianak.
\end{abstract}

\section{ABSTRACT}

Siam pontianak orange planlet's (Citrus nobilis Lour. var. microcarpa Hassk.) is one of the important fruits in Indonesia. Orange has a high economic value both in the form of fresh and processed and as a source of vitamins and minerals. The purpose of this research is to know the optimum concentration of atonic solution; concentration of Polyethylene Glycol (PEG) tolerant to drought stress for selection of Siam plantlets in vitro; knowing the interaction between an atonic solution and PEG 6000 for knowing and analyzing the specific expression character of a conjoined orange planlet tolerant of drought stress including total dissolved carbohydrate content. This research was conducted in $3 \times 3$ factorial experiments. Factor A was an atonic solution to 3 concentration levels: $0 \mathrm{~mL} / \mathrm{L}, 1 \mathrm{~mL} / \mathrm{L}$, and $2 \mathrm{~mL} / \mathrm{L}$. Factor B is PEG 6000 to 3 levels of concentration: $0 \% \mathrm{w} / \mathrm{v}, 3 \% \mathrm{w} / \mathrm{v}$, and $5 \% \mathrm{w} / \mathrm{v}$. Levene test, variance analysis at $5 \%$ real level. Variance analysis was performed at $5 \%$ real level. The results showed that atonic solution to high drought level significantly decreased total dissolved carbohydrate content. From the results of this study it can be concluded that atonic solution has no significant effect on increasing total dissolved carbohydrate content of plantlet of Siam Pontianak Orange. 


\section{PENDAHULUAN}

Jeruk merupakan salah satu komoditas buah-buahan yang penting di Indonesia. Selain sebagai sumber vitamin dan mineral, jeruk juga memiliki nilai ekonomis yang cukup tinggi baik dalam bentuk segar maupun bentuk olahan. Oleh karena itu, jeruk banyak digemari oleh semua lapisan masyarakat sehingga kebutuhan akan jeruk terus meningkat (Hatimah, 2000).

Selama ini jeruk hanya dikenal sebagai sumber vitamin $C$, padahal buah bulat ini juga mengandung sederetan zat gizi esensial lainnya, yang meliputi karbohidrat (zat gula dan serat makanan), potassium, folat, kalsium, thiamin, niacin, vitamin B6, fosfor, magnesium, tembaga, riboflavin, asam pantotenat, dan senyawa fotokimia. Keunggulan lainnya, jeruk tidak mengandung sodium, lemak, dan kolesterol. Kandungan kalorinya pun rendah, sehingga tidak akan membangkitkan kekhawatiran bagi mereka yang berupaya menurunkan bobot badan. Sebuah jeruk segar berukuran sedang hanya mengandung 60-80 Kkal. Karbohidrat dalam jeruk merupakan karbohidrat sederhana yaitu fruktosa, glukosa, dan sukrosa. Karbohidrat kompleksnya berupa polisakarida non-pati yang baik untuk kesehatan (Rahardi et al., 1999).

Di daerah tropika pada umumnya, termasuk Indonesia, memiliki tingkat curah hujan yang rendah sehingga pasokan air ke lahan pertanian menurun. Air merupakan salah satu faktor yang sangat penting untuk pertumbuhan tanaman jeruk manis, pembentukan buah, fotosintesis, dan lain-lain. Air juga sebagai komponen semua jaringan tanaman. Kandungan air pada daun dan tunas sekitar 50 sampai $75 \%$, pada buah lebih kurang $85 \%$ dan pada akar kira-kira 60 sampa $85 \%$. Air melarutkan unsur hara dan membawanya ke seluruh tubuh tanaman dan aktivitas kehidupan sel-sel dalam semua jaringan tanaman (Peter, 2012).

Kekurangan air dapat mengganggu aktivitas fisiologis maupun morfologis, sehingga mengakibatkan terhentinya pertumbuhan. Difisiensi air yang terus menerus akan menyebabkan perubahan yang irreversible (tidak dapat balik) dan pada gilirannya tumbuh akan mati (Haryati, 2003).

Upaya peningkatan produksi jeruk siam dapat dilakukan dengan pemberian Zat Perangsang Tumbuh (ZPT) (Septiatin, 2008). Atonik merupakan salah satu zat pengatur tumbuh golongan auksin pada tanaman. Pemakaian larutan atonik pada tanaman berfungsi untuk merangsang pertumbuhan akar tanaman agar lebih banyak, mengaktifkan penyerapan unsur hara, meningkatnya keluarnya kuncup dan buah serta memperbaiki kualitas panen (Permadi et al.,1989).

Hasil penelitian yang telah dilakukan oleh Mafakheri et al. (2011) yang menyatakan bahwa cekaman kekeringan terpaksa dilakukan pada saat pertumbuhan vegetativ berlangsung 
atau anthesis secara signifikan menurunkan protein terlarut meningkatkan kadar karbohidrat terlarut total. Varietas yang toleran terhadap cekaman kekeringan akan mengakumulasikan kadar karbohidrat terlarut total daripada varietas yang resisten terhadap cekaman kekeringan. Dalam makalah ini peneliti melaporkan pengaruh larutan atonik dan Polyethylene Glycol terhadap planlet jeruk siam pontianak pada kondisi cekaman kekeringan

\section{METODE}

\section{Alat dan Bahan}

Alat-alat yang di gunakan dalam penelitian ini adalah autoklaf, botol kultur, cawan petri, tabung reaksi, gelas ukur, erlenmeyer, labu takar, beaker glass, $\mathrm{pH}$ meter, bunsen, pinset, mikropipet, gunting, batang pengaduk, kompor, panci, laminar air flow cabinet (LAFC) merk ESCO, timbangan analitik ohaus, magnetic stirrer, spektrofotometer UV, pisau skalpel, mata pisau scalpel (One Med), peralatan diseksi, hand sprayer, tisu, alat tulis, solasi, plastic wrap, alumunium foil, dan kertas label.

Penelitian ini dilaksanakan pada bulan November 2017 di Laboratorium Botani Ruang In Vitro, Jurusan Biologi Fakultas Matematika dan Ilmu Pengetahuan Alam Universitas Lampung. Bahan-bahan yang digunakan dalam penelitian ini adalah media dasar Murashige dan Skoog siap pakai, Polietilen Glikol 6000 (PEG 6000), atonik, akuades, Benzine Amino Purine (BAP), Sukrosa, Plant Preservative Mixture (PPM), spritus, $\alpha$ napthol, $\mathrm{H}_{2} \mathrm{SO}_{4}$, alkohol $70 \%, 95 \%$ dan $96 \%$, larutan pemutih (Bayclean) (bahan aktif: Natrium Hipoklorit), gula pasir, agar-agar, biji jeruk varietas pontianak, myoinositol, Kalium Hidroksida (KOH), Asam Klorida $(\mathrm{HCl})$, Asam Sulfat $\left(\mathrm{H}_{2} \mathrm{SO}_{4}\right)$, dan fenol

\section{Prosedur}

Penelitian ini dilakukan dalam percobaan faktorial 3 x 3 . Faktor A adalah larutan atonik dengan 3 taraf konsentrasi : 0 mL/L, 1 mL/L, dan 2 mL/L. Faktor B adalah PEG 6000 dengan 3 taraf konsentrasi : $0 \% \mathrm{~b} / \mathrm{v}, 3 \% \mathrm{~b} / \mathrm{v}$, dan $5 \% \mathrm{~b} / \mathrm{v}$. Masing-masing konsentrasi dilakukan 4 kali pengulangan dan setiap ulangan terdiri dari 3 planlet jeruk siam pontianak dalam setiap botol kultur. Parameter dalam penelitian ini adalah semua nilai tengah $(\mu)$ kandungan karbohidrat terlarut total pada setiap planlet jeruk siam pontianak. 


\section{Sterilisasi Alat}

Alat-alat gelas dan dissecting set (skalpel, mata pisau skalpel, pinset) dicuci dengan detergen kemudian alat-alat tersebut dicuci dengan air mengalir dan diautoklaf. Alat dari bahan gelas ditutup plastik, sedangkan alat-alat dari bahan logam dan cawan petri dibungkus dengan kertas HVS. Semua alat tersebut disterilisasi dalam autoklaf pada temperatur $121{ }^{\circ} \mathrm{C}$, selama 30 menit.

\section{Persiapan Medium Tanam}

Medium yang digunakan dalam penelitian ini adalah Murashige dan Skoog (MS) padat. Pembuatan medium tanam MS sebanyak 1 liter adalah dengan cara menimbang media dasar Murashige dan Skoog use ready sebanyak 4,43 gram, kemudian dimasukkan ke dalam labu takar 1 liter. Akuades ditambahkan sampai tanda 1 liter dan $\mathrm{pH}$ diatur sampai 5,5. Untuk mendapatkan $\mathrm{pH}$ 5,5 dilakukan penambahan $\mathrm{KOH} 1 \mathrm{~N}$ atau $\mathrm{HCl} 1 \mathrm{~N}$. Larutan tersbut kemudian dipindahkan ke dalam wadah yang lebih besar lalu ditambahkan agar-agar sebanyak 7 gram/L, sukrosa 30 gram/L, dan PPM 0,5 ml/L. Larutan medium dipanaskan untuk melarutkan agaragar (sambil diaduk) sampai mendidih. Penambahan (Zat Pengatur Tumbuh) ZPT dilakukan setelah larutan medium diangkat, kemudian dituangkan ke dalam botol kultur sebanyak 20 $\mathrm{ml} /$ botol. Sterilisasi medium dengan menggunakan autoklaf dengan tekanan $17,5 \mathrm{psi}, 121{ }^{\circ} \mathrm{C}$ selama 15 menit.

\section{Persiapan Medium Seleksi}

Medium Murashige dan Skoog (MS) padat ditambah PEG 6000 dengan konsentrasi $0 \%$ (kontrol), $3 \%$, dan $5 \%$. Sebelum digunakan, PEG 6000 yang telah dilarutkan dengan akuades pada konsentrasi tertentu disaring menggunakan syringe filter yang mempunyai diameter $0,45 \mu \mathrm{m}$ sebanyak 2 kali, dilanjutkan filter berdiameter $0,22 \mu \mathrm{m}$ satu kali. Penyaringan dilakukan dalam ruang steril didalam LAFC. Selanjutnya PEG 6000 ditambahkan ke dalam medium MS. Sebelum digunakan, medium diinkubasikan selama 7 hari pada suhu kamar (25 ${ }^{\circ} \mathrm{C}$ ) untuk memastikan bahwa PEG 6000 telah tersaring dengan baik. Apabila dalam waktu 7 hari tidak terjadi kontaminasi pada medium, maka medium dapat digunakan.

\section{Sterilisasi Biji}

Biji dikupas dari kulitnya kemudian biji direndam dalam larutan bendix (fungisida) selama 30 menit, kemudian biji dibilas dengan akuades sebanyak 3 kali, lalu biji dikupas lapisan kulit 
arinya. Setelah itu biji direndam dengan bayclean $10 \%$ selama 10 menit dilanjutkan dengan bayclean $5 \%$ selama 15 menit. Setelah itu biji dibilas dengan akuades steril sebanyak 3 kali pengulangan. Semua kegiatan ini dilakukan dalam ruang steril di dalam LAFC.

\section{Penanaman}

Biji yang telah steril kemudian dipindahkan ke dalam cawan petri, selanjutnya biji ditanam pada medium MS 0. Penanaman biji jeruk siam pontianak dilakukan di dalam LAFC. Setiap botol kultur ditanami 3 biji, sehingga total biji yang ditanam sebanyak 108 biji dalam 36 botol kultur. Biji jeruk siam pontianak tersebut ditumbuhkan hingga menjadi planlet. Inkubasi kultur dilakukan pada ruangan dengan penyinaran sekitar 1000 lux, 24 jam/hari dan suhu sekitar 20 ${ }^{\circ} \mathrm{C}$.

\section{Induksi Planlet dengan Larutan Atonik}

Akar planlet yang akan ditanam mula-mula direndam dengan larutan atonik selama 10 menit. Larutan atonik terlebih dahulu dilarutkan dengan akuades pada 3 konsentrasi yaitu 0 $\mathrm{ml} / \mathrm{L}$ (kontrol), $1 \mathrm{ml} / \mathrm{L}, 2 \mathrm{ml} / \mathrm{L}$, kemudian disaring dengan menggunakan syringe filter dengan diameter 0,45 $\mu \mathrm{m}$ sebanyak 2 kali, dilanjutkan filter berdiameter $0,22 \mu \mathrm{m} 1$ kali.

\section{Penanaman Pada Medium Seleksi}

Planlet yang telah direndam dengan larutan atonik dipindahkan ke dalam cawan petri, selanjutnya planlet ditanam pada medium Murashige dan Skoog yang telah diberi PEG 6000 dengan berbagai konsentrasi. Penanaman planlet jeruk siam pontianak dilakukan di dalam LAFC. Setiap botol kultur ditanami 3 planlet, sehingga total planlet yang ditanam sebanyak 108 batang dalam 36 botol kultur. Inkubasi kultur dilakukan pada ruangan dengan penyinaran sekitar 1000 lux, 24 jam/hari dan suhu sekitar $20^{\circ} \mathrm{C}$.

\section{Pengamatan}

Kandungan karbohidrat terlarut total dihitung dengan mengambil dan menimbang sebanyak 0,1 gram kemudian menumbuk daun dengan mortar lalu diberi $10 \mathrm{ml}$ akuades, menyaring filtrat dengan kertas saring Whatman no. 1 lalu memasukkan kedalam tabung reaksi.

Selanjutnya filtrat diambil sebanyak $1 \mathrm{ml}$ lalu ditambahkan $1 \mathrm{ml} \mathrm{H}_{2} \mathrm{SO}_{4}$ lalu ditambahkan fenol sebanyak $2 \mathrm{ml}$. Selanjutnya filtrat dimasukkan kedalam kuvet dibaca pada panjang 
gelombang $490 \mathrm{~nm}$. Kandungan karbohidrat terlarut total dihitung dengan menggunakan metode fenol-sulfur menurut Witham et al. (1993).

Homogenitas ragam ditentukan dengan uji Levene pada taraf nyata 5\%. Analisis ragam dilakukan pada taraf nyata 5\%. Jika interaksi faktor A dan B tidak nyata,maka ditentukan main effect dari faktor A dan B dengan uji BNT pada taraf nyata 5\%. Jika interaksi nyata maka ditentukan simple effect larutan atonik pada setiap konsentrasi PEG 600 pada taraf nyata $5 \%$.

\section{HASIL DAN PEMBAHASAN}

Kandungan karbohidrat terlarut total pada tanaman akan meningkat seiring dengan meningkatnya kadar konsentrasi PEG yang ditambahkan pada medium tanam. Tanaman yang mengalami cekaman kekeringan terjadi penurunan zat tepung dan peningkatan kadar gula. Kandungan karbohidrat terlarut total planlet jeruk siam Pontianak setelah perlakuan dengan larutan atonik dan PEG 6000 ditunjukkan pada Tabel 1.

Tabel 1. Kandungan Karbohidrat Terlarut Total Planlet Jeruk Siam Pontianak (mg/gram)

\begin{tabular}{ccccc}
\hline PEG & \multicolumn{3}{c}{ Atonik $(\mathrm{mL} / \mathrm{L})(\mathrm{v} / \mathrm{v})$} & Nilai tengah \\
\cline { 2 - 4 } $\begin{array}{c}(0 \%) \\
(\mathrm{b} / \mathrm{v})\end{array}$ & 0 & 1 & 2 & \\
\hline 0 & $1,208 \pm 0,303$ & $0,673 \pm 0,336$ & $0,671 \pm 0,157$ & 0,850 \\
\hline 3 & $0,895 \pm 0,080$ & $1,415 \pm 0,331$ & $1,239 \pm 0,239$ & 1,183 \\
\hline 5 & $0,664 \pm 0,686$ & $0,936 \pm 0,129$ & $0,645 \pm 0,291$ & 0,748 \\
\hline Nilai Tengah & 0,922 & 1,008 & 0,851 & \\
\hline
\end{tabular}

Homogenitas ragam ditentukan dengan uji Levene pada taraf nyata 5\%. Analisis ragam dilakukan pada taraf nyata 5\%. Jika interaksi faktor A dan B tidak nyata,maka ditentukan main effect dari faktor A dan B dengan uji BNT pada taraf nyata 5\%. Jika interaksi nyata maka ditentukan simple effect larutan atonik pada setiap konsentrasi PEG 600 pada taraf nyata $5 \%$.

Analisis ragam pada taraf nyata 5\% menunjukkan bahwa larutan atonik tidak berpengaruh nyata terhadap kandungan karbohidrat terlarut total pada planlet jeruk siam pontianak $\left\{F_{\text {hit }}(0,323)<F_{\text {crit }}(3,554)\right\}$, PEG 6000 juga tidak berpengaruh nyata terhadap kandungan karbohidrat terlarut total pada planlet jeruk siam pontianak $\left\{F_{\text {hit }}(2,727)<F_{\text {crit }}\right.$ $(3,554)$. Tidak terdapat interaksi antara larutan atonik dan PEG 6000 terhadap kandungan karbohidrat terlarut total pada planlet jeruk siam pontianak $\left\{F_{\text {hit }}(1,532)<F_{\text {crit }}(2,927)\right\}$. Kandungan karbohidrat terlarut total meningkat pada konsentrasi larutan atonik $1 \mathrm{~mL} / \mathrm{L}$ dan PEG $60003 \%$ hal ini menandakan bahwa planlet jeruk siam pontianak toleran terhadap 
cekaman kekeringan pada konsetrasi tersebut. Pada konsentrasi larutan atonik $2 \mathrm{~mL} / \mathrm{L}$ dan PEG $60005 \%$ atau konsentrasi tertinggi, kandungan karbohidrat terlarut total menurun, hal ini disebabkan karena planlet jeruk siam pontianak menjadi resisten pada konsentrasi tersebut. Main effect larutan atonik dan PEG 6000 terhadap kandungan karbohidrat terlarut total pada planlet jeruk siam Pontianak ditunjukkan pada Gambar 1.

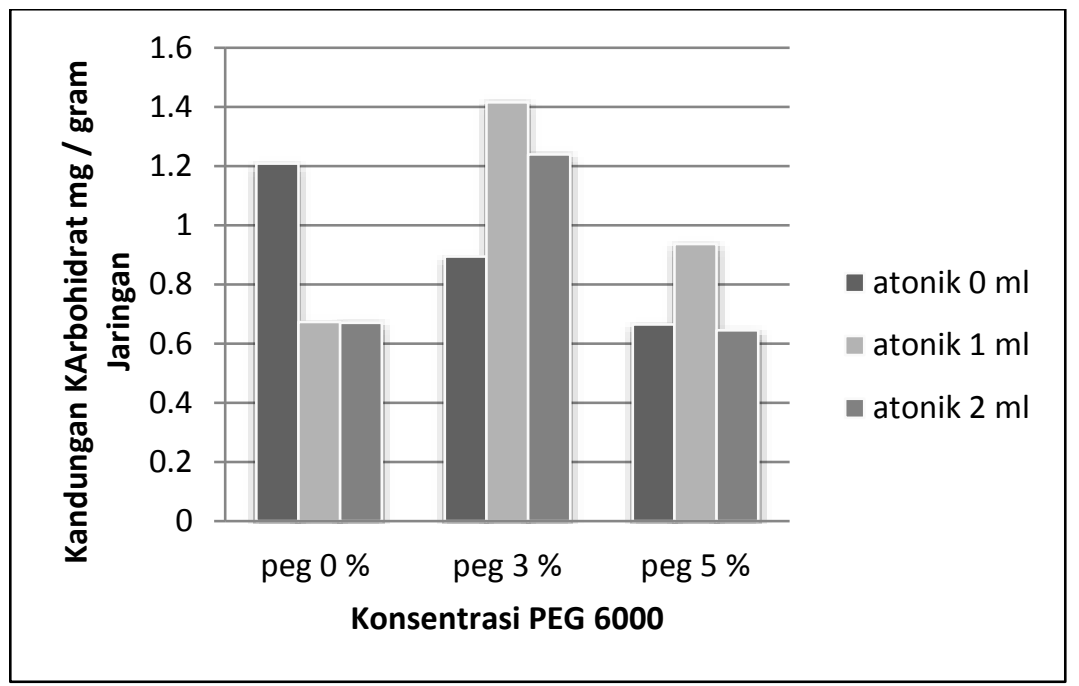

Gambar 1. Main Effect larutan atonik dan PEG 6000 terhadap kandungan karbohidrat terlarut total planlet jeruk siam Pontianak

Berdasarkan uji BNT pada taraf nyata $5 \%$ perlakuan larutan atonik $1 \mathrm{~mL} / \mathrm{L}$ dan PEG $60003 \%$ meningkat secara nyata, kandungan karbohidrat terlarut total pada planlet jeruk siam Pontianak sebesar 1,415 mg/gram, sedangkan pada perlakuan larutan atonik $2 \mathrm{~mL} / \mathrm{L}$ dan PEG $60005 \%$, kandungan karbohidrat terlarut total menurun secara nyata dengan kandungan karbohidrat terlarut total sebesar 0,645 mg/gram.

Hasil penelitian ini tidak sesuai dengan penelitian yang telah dilakukan oleh Zao et al. (2013) yang menyatakan kekeringan menyebabkan kandungan karbohidrat daun dan akar tebu meningkat nyata, namun pada varietas tahan kandungan karbohidrat dapat menurun kembali setelah pemberian air. Penelitian lain juga melaporkan bahwa pada level cekaman kekeringan yang sama, akumulasi gula pada akar lebih tinggi dibanding pada daun sehingga menyebabkan kandungan gula pada daun dan akar juga meningkat seiring dengan meningkatnya level cekaman kekeringan.Tri et al. (2013). Kekurangan air secara otomatis akan menyebabkan stomata menutup untuk menghindari kehilangan air yang berlebih. Menutupnya stomata akan mengurangi proses pertukaran gas untuk fotosintesis, sehingga produksi gula yang dihasilkan oleh fotosintesis akan menurun. Campbell et al. (2012). Perbedaan ini diduga berkaitan dengan 
perbedaan respon antara tanaman jeruk, tebu, dan jagung. Disamping itu kemungkinan ada perbedaan hasil yang diperoleh antara metode lapangan dengan metode laboratorium.

\section{KESIMPULAN}

Kandungan karbohidrat terlarut total pada planlet jeruk siam pontianak dengan perlakuan kombinasi larutan atonik dan PEG 6000 berbagai konsentrasi mengalami penurunan. Penurunan kandungan karbohidrat terlarut total terendah terdapat pada kombinasi konsentrasi larutan atonik 2 ml/L dengan PEG $60005 \%$, sedangkan kandungan karbohidrat terlarut total tertinggi terdapat pada kombinasi konsentrasi larutan atonik 1 ml/L dengan PEG $60003 \%$.

\section{DAFTAR PUSTAKA}

Campbell, A. Neil, B.R. Jane. 2012. Biology, Eighth Edition: Translation copyright. Erlangga. Jakarta.

Haryati. 2003. Pengaruh Cekaman Kekeringan Air Terhadap Pertumbuhan dan Hasil Tanaman. Fakultas Pertanian Universitas Sumatera Utara. Medan.

Hatimah, I. 2000. Strategi dan Metode Pembelajaran. Andira. Bandung.

Mafakheri, A., A. Siosemardeh, B. Bahramnejad, P. C. Stuik, Y. Sohrabi. 2011. Effect of Drought Stress and Subsequent Recovery on Protein, Carbohydrate Content, Catalase, and Peroxidase Activities in Three Chickpea (Cicer arietinum) Cultivars. Australian Journal of Crop Science, 5 (10) : 1255 - 1260.

Permadi, A. H., A. Wasito, dan E. Sumiati. 1989. Morfologi dan Pertumbuhan Kentang. Balai Penelitian Hortikultura. Lembang.

Peter, R. H., J. Tatuh, dan E. X. Johannes. 2012. Analisis Dampak Perubahan Iklim terhadap Produksi Beras Provinsi Sulawesi Utara Tahun 2013 - 2030. Eugenia, 18 (3).

Rahardi,P., Y.H. Indriani dan Haryono. 1999. Agribisnis Tanaman Buah. Penebar Swadaya. Jakarta.

Septiatin, dan Eatin. 2008. Apotek Hidup dari Rempah-Rempah, Tanaman Hias, dan Tanaman Liar. CV. Yrama Widya. Bandung.

Tri, M., S. Y. Kusumadewi, Y. B. Charles, dan I. G. B. Adwinta. 2013. Respon Tanaman Jagung Varietas Lokal NTT Umur Sangat Genjah (Pena Tunu' Ana') terhadap Cekaman Kekeringan. Berita Biologi, 14 (1).

Witham, Devlin dan M. Robert. 1993. Exercise in Plant Physiology. Second Edition. Prindle, Weber \& Scimdt. Boston.

Zao, D., B. Glaz, J.C. Comntock. 2013. Sugarcane leaf photoshinthesis and growth characters during development of water deficit stress, Crop Science, 80:1066 - 1075. 